\title{
KEWAJIBAN ADVOKAT DALAM UPAYA MENCEGAH TRANSAKSI KEUANGAN MENCURIGAKAN
}

\section{Yudhi Ongkowijaya, Helvis, Markoni}

Universitas Esa Unggul Jakarta, Indonesia

Email: yudhi_ongko@yahoo.co.id,mey.mooi@yahoo.com,sh.markoni@gmail.com

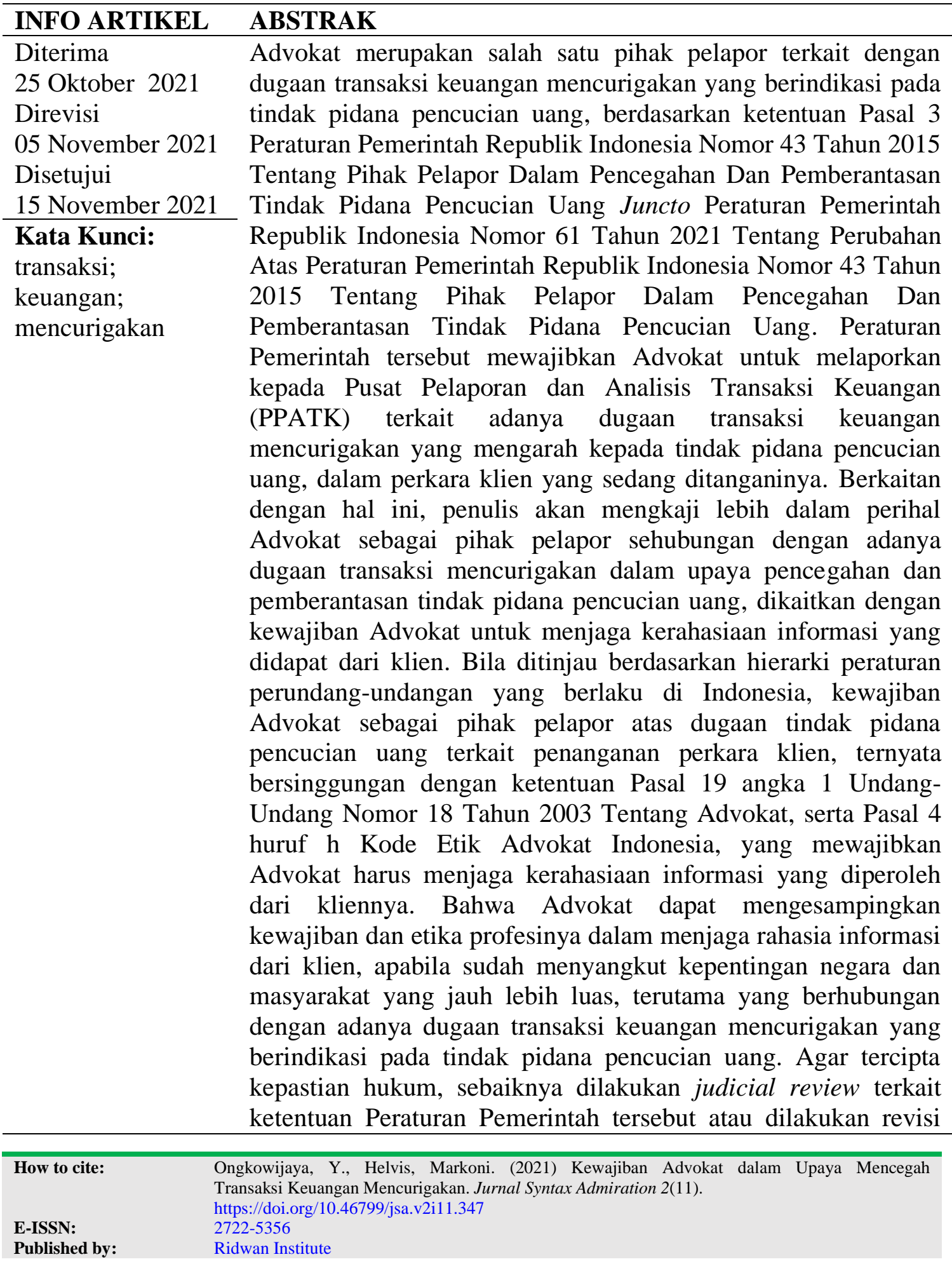


Undang-Undang Advokat agar lebih mengakomodir kedudukan Advokat dalam menjalankan kewajibannya menjaga kerahasiaan informasi sekaligus ikut berperan mencegah terjadinya transaksi keuangan mencurigakan yang mengarah kepada tindak pidana pencucian uang.

\section{ABSTRACT}

Advocates are one of the reporting parties related to alleged suspicious financial transactions. Regulations that indicate the crime of money laundering, based on the provisions of Article 3 of The Government Regulation of The Republic of Indonesia Number 43 of 2015 concerning Reporting Parties In The Prevention and Eradication of The Crime of Money Laundering Juncto The Government Regulation of The Republic of Indonesia Number 61 of 2021 concerning Amendments to Government Regulation of The Republic of Indonesia Number 43 of 2015 concerning Reporting Parties In The Prevention and Eradication of Crimes Money Laundering. The Government Regulation requires Advocates to report to the Financial Transaction Reports and Analysis Center (PPATK) regarding suspected suspicious financial transactions that lead to money laundering. In this regard, the author will examine more deeply the matter of Advocates as reporting parties in connection with suspected suspicious transactions in an effort to prevent and eradicate money laundering, associated with the obligation of Advocates to maintain the confidentiality of information obtained from clients. When viewed based on the hierarchy of laws and regulations in force in Indonesia, the obligation of Advocates as reporting parties for alleged money laundering crimes related to handling client cases, turns out to be contrary to the provisions of Article 19 point 1 of Law Number 18 of 2003 concerning Advocates, as well as Article 4 letter $h$ of the Indonesian Advocates' Code of Ethics, which requires Advocates to maintain the confidentiality of information obtained from their clients. That Advocates can waive their obligations and professional ethics in keeping confidential information from clients, if it involves the interests of the state and the wider community, especially those related to suspected suspicious financial transactions with indications of money laundering. In order to create a law, it is advisable to conduct a legal review related to The Government Regulation above or to revise the

Keywords: suspicious; financial; transactions Law in order to better accommodate the position of Advocates in maintaining the confidentiality of information while at the same time playing a role in preventing suspicious financial transactions that lead to the crime of money laundering. 


\section{Pendahuluan}

Kata Advokat, secara etimologis berasal dari bahasa latin, yakni Advocatus, yang berarti to defend, to call to one's aid to vouch or warrant. Atau to speak in favour of or depend by argument, to support, indicate, or recommended publicy (Soekanto, 2007). Berawal dari seorang tokoh di zaman Romawi Antik (jauh sebelum Tahun Masehi), yaitu Patronus, profesi Advokat dikenal sebagai pekerjaan terhormat dan dihargai hingga saat ini. Berdasarkan spirit dan latar historis itulah, maka muncul istilah officium nobile yang dilekatkan kepada profesi Advokat. Pekerjaan Advokat adalah pekerjaan terhormat (officium nobile). Dalam bahasa latin, kata nobilis menunjuk pada orangorang terkemuka dan para bangsawan. Nobilis berarti mulia, luhur, utama, yang baik, yang sebaik-baiknya. Nobilis juga dikaitkan dengan bangsawan, kebangsawanan, kalangan atas, berpangkat tinggi, keluhuran jiwa, keunggulan. Sedangkan officium berarti jasa, kesediaan menolong atau kesediaan melayani. Jadi officium nobile merupakan perpaduan antara niat luhur dan status sebagai orang-orang terkemuka serta para advocatus saat itu dalam menolong para pencari keadilan. Mereka melakukan pembelaan terhadap masyarakat yang membutuhkan, tanpa dibayar. Inilah latar historis Advokat sebagai officium nobile (Parera, 2018).

Jabatan yang dipangku oleh Advokat adalah jabatan kepercayaan (vertrouwensambt) dan justru oleh karena itu, seseorang bersedia mempercayakan sesuatu kepadanya, dalam hal ini yaitu penanganan permasalahan dan perkara dari orang yang bersangkutan. Sebagai orang kepercayaan (vertrouwensperson), Advokat berkewajiban untuk merahasiakan informasi dari kasus kliennya, terkait dengan semua apa yang diketahui dan diberitahukan kepadanya selaku Advokat dalam kapasitasnya sebagai Kuasa Hukum/Penasihat Hukum. Advokat harus merahasiakan segala yang diketahui dan diberitahukan kepadanya oleh klien, baik pada waktu diadakan pembicaraan-pembicaraan sebagai persiapan untuk penanganan suatu perkara, maupun pada saat penanganan perkara tersebut sedang berlangsung, dan bahkan setelah Advokat tidak lagi menangani perkara kliennya. Hal ini sesuai dengan apa yang tercantum di dalam Pasal 4 huruf h Kode Etik Advokat Indonesia yang menyatakan bahwa Advokat wajib memegang rahasia jabatan tentang hal-hal yang diberitahukan oleh klien secara kepercayaan dan wajib tetap menjaga rahasia itu setelah berakhirnya hubungan antara Advokat dan klien itu (K. K. A. Indonesia, 2002).

Secara umum Advokat wajib merahasiakan segala informasi dan keterangan yang diperoleh dari klien terkait penanganan perkaranya, kecuali diperintahkan oleh undangundang bahwa Advokat tidak wajib merahasiakan keterangan yang diperlukan yang berkaitan dengan perkara kliennya. Hal ini tertuang di dalam Pasal 19 angka 1 UndangUndang Nomor 18 Tahun 2003 Tentang Advokat yang menyatakan bahwa Advokat wajib merahasiakan segala sesuatu yang diketahui atau diperoleh dari kliennya karena hubungan profesinya, kecuali ditentukan lain oleh Undang-Undang (Pattawijaya, 2021).

Kewajiban untuk merahasiakan, selain diharuskan oleh undang-undang, juga untuk kepentingan Advokat itu sendiri. Seorang Advokat yang tidak dapat membatasi diri, akan mengalami akibatnya di dalam praktik, ia akan segera kehilangan 
kepercayaan publik dan ia tidak lagi dianggap sebagai orang kepercayaan (vertrouwenspersoon). Berkaitan dengan penanganan perkara yang dilakukan oleh Advokat, bisa jadi klien merupakan pelaku tindak pidana pencucian uang yang menggunakan jasa Advokat untuk membelanya atas suatu kasus yang berkaitan dengan transaksi yang diperoleh dari hasil perbuatan tindak pidana. Profesi Advokat adalah salah satu profesi yang paling rentan menjadi gatekeeper, karena profesi tersebut sangat kuat posisinya untuk membela diri atau pihak lain atau melindungi diri atau pihak lain. Hal-hal tersebut dijunjung tinggi demi perlindungan kerahasiaan informasi antara Advokat dan klien serta kemandirian Advokat dalam membela kliennya (Yuristara, 2018).

Advokat adalah salah satu bagian dari penegak hukum. Sebagai bagian dari penegak hukum, Advokat mempunyai tugas dan fungsi sebagai pihak yang oleh negara diharapkan mempunyai andil dalam rangka menciptakan keadilan dan kepastian hukum dalam masyarakat. Jadi dapat dibayangkan apa yang terjadi apabila terdapat Advokat yang malah secara sadar membantu terjadinya perbuatan melawan hukum melalui penyelewengan maupun penyelundupan hukum dengan alibi untuk kepentingan pembelaan perkara kliennya. Tentu risiko yang dihadapi bukan hanya yang bersangkutan akan berurusan dengan proses pidana, tetapi juga dapat berdampak pada menurunnya martabat dan kehormatan profesi Advokat secara keseluruhan.

Dari uraian di atas, terlihat bahwa profesi Advokat memiliki karakteristik yang tidak jauh berbeda dengan berbagai penyedia jasa lainnya terutama mengenai risiko yang dihadapi apabila tidak menerapkan prinsip kehati-hatian dalam menjalani profesinya. Oleh karena itu, dalam upaya meminimalkan risiko melalui penerapan prinsip tata kelola yang baik (good governance) dan memperhatikan praktik-praktik yang baik secara internasional (international best practice) serta dalam upaya memberikan pelayanan terbaik bagi masyarakat, peran Advokat sangat dinantikan dalam memerangi kegiatan pencucian uang di Indonesia. Terbitnya Peraturan Pemerintah Republik Indonesia Nomor 43 Tahun 2015 Tentang Pihak Pelapor Dalam Pencegahan Dan Pemberantasan Tindak Pidana Pencucian Uang, yang kemudian diubah dengan Peraturan Pemerintah Republik Indonesia Nomor 61 Tahun 2021 Tentang Perubahan Atas Peraturan Pemerintah Republik Indonesia Nomor 43 Tahun 2015 Tentang Pihak Pelapor Dalam Pencegahan Dan Pemberantasan Tindak Pidana Pencucian Uang, dimana di dalamnya ditegaskan bahwa Advokat sebagai salah satu pihak pelapor atas dugaan tindak pidana pencucian uang atas perkara klien yang sedang ditanganinya. Peraturan Pemerintah ini merupakan peraturan pelaksana ketentuan sebagaimana dimaksud dalam Pasal 17 angka 2 Undang-Undang Nomor 8 Tahun 2010 Tentang Pencegahan Dan Pemberantasan Tindak Pidana Pencucian Uang.

Peraturan Pemerintah ini mewajibkan Advokat untuk melaporkan kepada Pusat Pelaporan dan Analisis Transaksi Keuangan (PPATK) terkait adanya dugaan transaksi keuangan mencurigakan yang mengarah kepada tindak pidana pencucian uang terhadap perkara yang sedang ditangani olehnya. Berkaitan dengan hal ini, penulis akan mengkaji lebih dalam perihal Advokat sebagai pihak pelapor sehubungan dengan adanya dugaan 
transaksi mencurigakan dalam upaya pencegahan dan pemberantasan tindak pidana pencucian uang, dikaitkan dengan penanganan perkara yang sedang ditangani olehnya. Berkaitan dengan Pasal 3 Peraturan Pemerintah Republik Indonesia Nomor 43 Tahun 2015 Tentang Pihak Pelapor Dalam Pencegahan Dan Pemberantasan Tindak Pidana Pencucian Uang Juncto Peraturan Pemerintah Republik Indonesia Nomor 61 Tahun 2021 Tentang Perubahan Atas Peraturan Pemerintah Republik Indonesia Nomor 43 Tahun 2015 Tentang Pihak Pelapor Dalam Pencegahan Dan Pemberantasan Tindak Pidana Pencucian Uang, ditegaskan bahwa Advokat sebagai pihak pelapor atas dugaan tindak pidana pencucian uang dalam perkara yang sedang ditanganinya. Terkait hal tersebut, bila ditinjau berdasarkan hierarki peraturan perundang-undangan yang berlaku di Indonesia, kewajiban Advokat sebagai pihak pelapor atas dugaan tindak pidana pencucian uang terkait penanganan perkara, sebagaimana diwajibkan oleh Peraturan Pemerintah Nomor 43 Tahun 2015 Tentang Pihak Pelapor Dalam Pencegahan Dan Pemberantasan Tindak Pidana Pencucian Uang Juncto Peraturan Pemerintah Nomor 61 Tahun 2021 Tentang Perubahan Atas Peraturan Pemerintah Nomor 43 Tahun 2015 Tentang Pihak Pelapor Dalam Pencegahan Dan Pemberantasan Tindak Pidana Pencucian Uang, ternyata dapat mengesampingkan ketentuan Undang-undang Nomor 18 Tahun 2003 Tentang Advokat, yang mewajibkan Advokat harus menjaga kerahasiaan informasi yang diperoleh dari kliennya sesuai Pasal 19 angka 1, serta Pasal 4 huruf h Kode Etik Advokat Indonesia. Hal ini perlu dikaji lebih dalam untuk mengetahui pengaruh Peraturan Pemerintah Republik Indonesia Nomor 43 Tahun 2015 sebagaimana yang telah diubah dengan Peraturan Pemerintah Republik Indonesia Nomor 61 Tahun 2021 Tentang Perubahan Atas Peraturan Pemerintah Republik Indonesia Nomor 43 Tahun 2015 Tentang Pihak Pelapor Dalam Pencegahan Dan Pemberantasan Tindak Pidana Pencucian Uang, terhadap Advokat sebagai pihak pelapor dalam pencegahan dan pemberantasan tindak pidana pencucian uang terkait kerahasiaan informasi sehubungan dengan penanganan perkara kliennya. Berdasarkan latar belakang tersebut peneliti mengambil judul "Kewajiban Advokat Dalam Upaya Mencegah Praktik Transaksi Keuangan Mencurigakan".

Pengertian kepastian hukum tersebut sejalan dengan pendapat dari E. Fernando M. Manulang yang mengemukakan pengertian kepastian hukum merupakan nilai yang pada prinsipnya memberikan perlindungan hukum bagi setiap warga negara dari kekuasaan yang sewenang-wenang, sehingga hukum memberikan tanggung jawab pada negara untuk menjalankannya, dalam hal ini tampak relasi antara persoalan kepastian hukum dengan Negara. (Manullang \& Berkeadilan, 2007) Soedikno Mertokusumo menyebutkan kepastian hukum sebagai perlindungan yustisiabel terhadap tindakan sewenang-wenang, yang berarti bahwa seseorang akan dapat memperoleh sesuatu yang diharapkan dalam keadaan tertentu.

\section{Metode Penelitian}

Penelitian ini dilakukan secara deskriptif analitis, yaitu memberikan gambaran secermat mungkin mengenai fakta-fakta yang ada, baik berupa data sekunder bahan 
hukum primer, seperti peraturan perundang-undangan, data sekunder bahan sekunder berupa pendapat para ahli, hasil-hasil penulisan, hasil karya dari kalangan hukum, serta bahan hukum tersier berupa data yang didapat dari majalah dan internet yang berkaitan dengan penelitian.

Metode pendekatan yang digunakan dalam penelitian ini secara yuridis normatif, yaitu suatu metode di mana hukum dikonsepsikan sebagai norma, kaidah, asas atau dogma. Metode pendekatan dalam penulisan ini menggunakan data sekunder yang terdiri dari bahan hukum primer dan bahan hukum sekunder, serta bahan hukum tersier. Lebih jauh dengan pemakaian pendekatan metode ini dimaksudkan untuk mengetahui peraturan-peraturan atau teori-teori yang ada, khususnya yang berhubungan dengan kewajiban Advokat dalam menyikapi dugaan transaksi keuangan mencurigakan dalam kaitannya dengan pembatasan transaksi keuangan yang wajib dilaporkan kepada PPATK terhadap perkara yang sedang ditangani oleh Advokat, serta kedudukan Advokat terkait kewajibannya menjaga kerahasiaan informasi dalam upaya mencegah tindak pidana pencucian uang.

Penelitian ini dilakukan dalam dua tahap yaitu melalui penelitian kepustakaan dan data lapangan. Sedangkan teknik pengumpulan data dilakukan dengan studi dokumen dan wawancara. Analisis data dilakukan dengan menggunakan metode analisis yuridis kuantitatif, yaitu metode penulisan yang bertitik tolak dari norma-norma, asas-asas dan peraturan perundang-undangan yang ada sebagai norma hukum positif yang kemudian dianalisis secara kualitatif dan dilaporkan secara deskriptif. Data yang diperoleh pada dasarnya merupakan data tataran yang dianalisis secara deskriptif kualitatif, yaitu data yang terkumpul dituangkan dalam bentuk uraian logis dan sistematis yang menghubungkan fakta yang ada dengan berbagai peraturan yang berlaku. Analisa akan dituangkan dalam bentuk kalimat yang ringkas dan jelas. Dalam penarikan kesimpulan, peneliti menggunakan metode induktif yaitu suatu metode yang berhubungan dengan permasalahan yang diteliti dari peraturan-peraturan atau prinsip-prinsip khusus menuju penelitian yang bersifat umum.

\section{Hasil dan Pembahasan}

\section{Kewajiban Advokat Dalam Upaya Pencegahan Dan Pemberantasan Tindak Pidana Pencucian Uang}

Advokat merupakan salah satu profesi selain Notaris, Pejabat Pembuat Akta Tanah, Akuntan, Akuntan Publik, dan Perencana Keuangan yang wajib menyampaikan laporan tranksaksi mencurigakan kepada PPATK, sebagaimana diatur dalam Peraturan Pemerintah Republik Indonesia Nomor 43 Tahun 2015 Juncto Peraturan Pemerintah Republik Indonesia Nomor 61 Tahun 2021 Tentang Perubahan Atas Peraturan Pemerintah Republik Indonesia Nomor 43 Tahun 2015 Tentang Pihak Pelapor Dalam Pencegahan Dan Pemberantasan Tindak Pidana Pencucian Uang. Munculnya peraturan tersebut membuat kalangan profesi Advokat dan kalangan terkait mempertanyakan mengenai kewajiban Advokat sebagai Pihak Pelapor terhadap transaksi keuangan mencurigakan tersebut. 
Peranan dari Advokat dalam upaya memberantas dan mencegah transaksi keuangan mencurigakan adalah dengan :

1. Kegiatan Mengenali Pengguna Jasa

Sesuai dengan ketentuan dalam Pasal 27 Undang-Undang Republik Indonesia Nomor 8 Tahun 2010 Tentang Pencegahan Dan Pemberantasan Tindak Pidana Pencucian Uang yang menyatakan : (R. Indonesia, 2010)

Pasal 27

1) Penyedia barang dan/atau jasa lain sebagaimana dimaksud dalam Pasal 17 ayat 1 huruf $b$ wajib menyampaikan laporan transaksi yang dilakukan oleh pengguna jasa dengan mata uang Rupiah dan/atau mata uang asing yang nilainya paling sedikit atau setara dengan Rp. 500.000.000,- (lima ratus juta Rupiah) kepada PPATK.

2) Laporan transaksi sebagaimana dimaksud pada ayat 1 disampaikan paling lama 14 (empat belas) hari kerja terhitung sejak tanggal transaksi dilakukan.

3) Penyedia barang dan/atau jasa lain yang tidak menyampaikan laporan kepada PPATK sebagaimana dimaksud pada ayat 1 dan ayat 2 dikenai sanksi administrasi.

2. Pengelolaan Risiko

Penerapan prinsip mengenal pengguna jasa merupakan bagian penting bagi manajemen risiko yang baik, terutama dalam pengelolaan risiko reputasi, risiko operasi, risiko hukum, dan risiko konsentrasi, yang mana satu dengan lainnya saling berhubungan. Risiko reputasi berkaitan dengan sifat dari bisnis suatu industri, yang membutuhkan kepercayaan dari nasabah atau pengguna jasa. Publikasi negatif, entah akurat ataupun tidak, bagi suatu industri akan menyebabkan kehilangan kepercayaan atas integritas industri yang bersangkutan (Fadjar, 2003).

3. Penatausahaan Dokumen

Dalam rangka penerapan prinsip mengenal pengguna jasa, pihak pelapor memiliki kewajiban menyimpan catatan dan dokumen identitas pelaku transaksi paling singkat 5 (lima) tahun sejak berakhirnya hubungan usaha. Sama halnya bagi profesi Advokat dan PPATK yang memang dalam kegiatannya melakukan pengumpulan dokumen dan informasi untuk alat bukti, maka penatausahaan dokumen menjadi hal yang sangat vital (Lotulung, 1994).

4. Memenuhi Prinsip Good Corporate Governance

Saat ini semua perusahaan termasuk profesi, untuk tetap bisa menjalankan fungsinya dengan baik, maka penerapan prinsip-prinsip Good Corporate Governance tidak bisa dihindari, dengan memperhatikan karakteristik perusahaan atau profesi yang dijalani agar tidak melanggar ketentuan perundang-perundangan yang berlaku.

Penanganan setiap perkara hukum, sudah sepatutnya dilakukan oleh seorang Advokat. Bahwa secara wewenang, Advokat sudah sesuai pada tempatnya dimana kewenangan memberikan bantuan hukum itu berada di tangan Advokat sebagai 
salah satu bagian dari penegak hukum serta dalam rangka upaya penegakan hukum. Kewenangan yang diharapkan dari seorang Advokat sebagai salah satu profesi yang diwajibkan oleh Peraturan Pemerintah Nomor 43 Tahun 2015 Juncto Peraturan Pemerintah Nomor 61 Tahun 2021 Tentang Perubahan Atas Peraturan Pemerintah Nomor 43 Tahun 2015 Tentang Pihak Pelapor Dalam Pencegahan Dan Pemberantasan Tindak Pidana Pencucian Uang, adalah bertindak sebagai pihak pelapor dalam membantu negara guna mencegah dan memberantas praktik transaksi keuangan mencurigakan dengan cara melaporkan kepada PPATK terkait adanya transaksi keuangan mencurigakan sebagaimana dimaksud dalam UndangUndang Republik Indonesia Nomor 8 Tahun 2010 Tentang Pencegahan Dan Pemberantasan Tindak Pidana Pencucian Uang serta melakukan upaya mengenali para pengguna jasa sebagaimana dimaksud dalam Peraturan Pusat Pelaporan Dan Analisis Transaksi Keuangan Nomor 10 Tahun 2017 Tentang Penerapan Prinsip Mengenali Pengguna Jasa Bagi Advokat (Marzuki \& SH, 2021).

Dalam kenyataannya, kewajiban yang diberikan kepada Advokat untuk bertindak sebagai pihak pelapor terkait adanya dugaan transaksi keuangan mencurigakan, terbentur dengan kewajiban Advokat untuk merahasiakan informasi yang diperoleh dari kliennya. Di satu sisi, penegakan hukum dalam rangka pemberantasan tindak pidana pencucian uang haruslah dijalankan secara tegak lurus, di sisi yang lain, Advokat juga terkendala dengan situasi yang menyulitkan, yaitu antara memilih menjadi idealis melalui pelaksanaan kewenangannya tersebut dalam rangka penegakan hukum, dengan risiko ditinggal pergi klien dan risiko tidak mendapatkan pekerjaan karena tentu klien sudah lebih dahulu berpikiran yang macam-macam terhadap Advokat yang hendak membuat laporan terhadap kliennya sendiri sehubungan dengan adanya dugaan transaksi keuangan mencurigakan dalam penanganan perkara yang sedang ditangani, atau, menjadi realis melalui pembelaan kepentingan klien apa adanya tanpa mempedulikan kepentingan umum yang jauh lebih luas, dengan harapan mendapat pundi-pundi materi yang mungkin nilainya akan sangat cukup dan memuaskan (Lotulung, 1994).

Dalam hal ini peneliti berpendapat bahwa walaupun Advokat terikat pada kewajiban menurut undang-undang dan Kode Etik Profesi guna menjaga kerahasiaan informasi dari klien, namun dalam rangka upaya mencegah praktik transaksi keuangan mencurigakan serta guna memberantas tindak pidana pencucian uang, Advokat dapat mengesampingkan etika dan kewajibannya, sehingga diperbolehkan untuk melaporkan segala transaksi keuangan mencurigakan yang berindikasi pada tindak pidana pencucian uang sekalipun berasal dari kliennya sendiri, karena hal tersebut sudah bukan lagi masalah hubungan privilege rahasia antara Advokat dan klien, akan tetapi jauh lebih besar lagi menyangkut kepentingan negara dan masyarakat luas yang jelas dirugikan oleh karena perbuatan pencucian uang. Advokat sebagai bagian dari penegak hukum, harus turut menegakkan hukum, tidak boleh dikendalikan oleh kliennya 
atau lebih mementingkan kebutuhan dan kepentingan kliennya dibandingkan menegakkan aturan hukum yang berlaku (Hsb, 2011).

2. Kedudukan Advokat Terkait Kewajibannya Menjaga Kerahasiaan Informasi Dalam Upaya Pencegahan Dan Pemberantasan Tindak Pidana Pencucian Uang

Advokat termasuk salah satu profesi yang dikenakan wajib lapor ke PPATK jika menemukan transaksi keuangan mencurigakan. Kewajiban ini tercantum dalam Peraturan Pemerintah Nomor 43 Tahun 2015 Juncto Peraturan Pemerintah Nomor 61 Tahun 2021 Tentang Perubahan Atas Peraturan Pemerintah Nomor 43 Tahun 2015 Tentang Pihak Pelapor Dalam Pencegahan Dan Pemberantasan Tindak Pidana Pencucian Uang. Peraturan Pemerintah ini mewajibkan Advokat sebagai pihak pelapor atas dugaan tindak pidana terhadap penanganan perkara yang sedang ataupun pernah dilakukan oleh Advokat, sedangkan dalam ketentuan Pasal 19 angka 1 Undang-Undang Nomor 18 Tahun 2003 Tentang Advokat dan Pasal 4 huruf h Kode Etik Advokat Indonesia, mewajibkan Advokat untuk merahasiakan atau tidak memberitahukan segala informasi dan keterangan yang berkaitan dengan kliennya kecuali undang-undang menentukan lain, sehingga sebenarnya mengakibatkan Peraturan Pemerintah Nomor 43 Tahun 2015 Juncto Peraturan Pemerintah Nomor 61 Tahun 2021 Tentang Perubahan Atas Peraturan Pemerintah Nomor 43 Tahun 2015 Tentang Pihak Pelapor Dalam Pencegahan Dan Pemberantasan Tindak Pidana Pencucian Uang ini, pada prinsipnya dapat dinyatakan tidak mempunyai kekuatan hukum sebagaimana dimaksud dalam Pasal 7 Undang-Undang Nomor 12 Tahun 2011 Tentang Pembentukan Peraturan Perundang-Undangan yang menyebutkan jenis dan hierarki peraturan perundang-undangan terdiri atas : (Nomor, 12 C.E.)

1. Undang-Undang Dasar Negara Republik Indonesia Tahun 1945;

2. Ketetapan Majelis Permusyawaratan Rakyat;

3. Undang-Undang/Peraturan Pemerintah Pengganti Undang-Undang;

4. Peraturan Pemerintah;

5. Peraturan Presiden;

6. Peraturan Daerah Provinsi;

7. Peraturan Daerah Kabupaten/Kota.

Secara hierarki tata hukum dan sistem perundang-undangan di Indonesia, bahwa kedudukan Undang-Undang Advokat, yang memerintahkan Advokat untuk merahasiakan segala informasi dari klien, lebih tinggi tingkatannya daripada Peraturan Pemerintah tersebut. Dalam hierarki tata hukum dan sistem perundangundangan di Indonesia secara tegas dinyatakan negara Indonesia menganut sistem hukum, yaitu peraturan perundang-undangan yang lebih tinggi tingkatannya mempunyai kedudukan lebih tinggi dibandingkan dengan peraturan perundangundangan yang tingkatannya berada dibawahnya. Sehingga ketentuan peraturan perundang-undangan yang lebih rendah tidak boleh bertentangan dengan peraturan perundang-undangan yang lebih tinggi tingkatannya (lex superiori derogat legi inferiori) karena bila dilanggar ketentuan ini akan mengakibatkan ketentuan tersebut tidak mempunyai kekuatan hukum. 
Berdasarkan hal tersebut, peneliti memiliki pendapat lain, dikarenakan Advokat wajib melaporkan transaksi keuangan mencurigakan, maka yang dilakukan tersebut tidak berkaitan lagi dengan hubungan kerahasiaan informasi antara Advokat dan klien, karena tindak pidana pencucian uang merupakan tindakan pelanggaran hukum yang akibatnya sangat merugikan negara dan masyarakat luas. Advokat adalah salah satu pilar penegak hukum yang berwenang untuk menjalankan kewajiban dan jabatan sebaik- baiknya, sehingga tidak diperbolehkan seorang Advokat dapat dikendalikan oleh klien atau lebih mementingkan keuntungan klien terlebih dahulu dibandingkan menegakkan peraturan yang telah ditetapkan (Rahardjo \& Dimyati, 2002).

Bahwa pembahasan mengenai kedudukan Advokat sehubungan dengan kewajibannya menjaga kerahasiaan informasi klien ini menimbulkan polemik antara peraturan perundang-undangan yang ada, sehingga menimbulkan ketidakpastian hukum terhadap profesi Advokat, sedangkan terkait dengan kepastian hukum, dalam hal ini undang-undang hendaknya memberikan kepastian mengenai kedudukan Advokat dalam kewajibannya menjaga kerahasiaan informasi klien, dihubungkan dengan kewajiban lainnya untuk bertindak sebagai pihak pelapor apabila terdapat indikasi transaksi keuangan mencurigakan dalam penanganan perkara kliennya, untuk itu teori kepastian hukum dipergunakan apabila suatu peraturan dibuat dan diundangkan serta diatur secara jelas dan logis, yang mengandung pengertian sebagai berikut :

a. Adanya aturan hukum yang konsisten dan dapat diterapkan, yang ditetapkan oleh negara;

b. Aparat pemerintah menerapkan aturan hukum tersebut secara konsisten dan berpegang pada aturan hukum tersebut;

c. Sebagian besar rakyat pada dasarnya konform (mengikuti) pada aturan tersebut;

d. Hakim yang bebas dan tidak memihak secara konsisten menerapkan aturan hukum tersebut (Wairocana, 2008).

Bahwa batasan Advokat dalam menjaga kerahasiaan informasi dari klien memang hanyalah ketentuan undang-undang, sebagaimana isi Pasal 19 angka 1 Undang-Undang Advokat. Dengan demikian hanya undang-undang saja yang dapat "memaksa" Advokat untuk membuka rahasia informasi kliennya. Dalam hal ini peneliti berpendapat, terkait rahasia informasi yang dimaksud disini bukan berarti menjaga rahasia secara keseluruhan tanpa batas, tetapi apabila menyangkut kepada kepentingan negara dan masyarakat luas terkait transaksi keuangan mencurigakan yang berindikasi pada tindak pidana pencucian uang, maka membuka rahasia informasi menjadi suatu kewajiban profesi dalam rangka proses penegakan hukum.

Namun demikian, demi terciptanya kepastian hukum terkait dengan kedudukan Advokat dalam kewajibannya menjaga kerahasiaan informasi dari klien, dihubungkan dengan kewajiban lainnya sebagai pihak pelapor apabila ada dugaan transaksi keuangan mencurigakan yang berindikasi pada tindak pidana pencucian uang, maka peneliti berpendapat, dengan mengacu kepada ketentuan di dalam Undang-Undang Nomor 12 Tahun 2011 Tentang Pembentukan Peraturan Perundang- 
Undangan, secara hierarki, kedudukan Peraturan Pemerintah Nomor 43 Tahun 2015 Tentang Pihak Pelapor Dalam Pencegahan Dan Pemberantasan Tindak Pidana Pencucian Uang Juncto Peraturan Pemerintah Nomor 61 Tahun 2021 Tentang Perubahan Atas Peraturan Pemerintah Nomor 43 Tahun 2015 Tentang Pihak Pelapor Dalam Pencegahan Dan Pemberantasan Tindak Pidana Pencucian Uang, berada di bawah Undang-Undang Nomor 18 Tahun 2003 Tentang Advokat. Oleh karena itu, agar sejalan dengan hierarki peraturan perundang-undangan yang berlaku di Indonesia, berdasarkan ketentuan Pasal 31 Angka 1 dan 2 Undang-Undang Nomor 3 Tahun 2009 Tentang Perubahan Kedua Atas Undang-Undang Nomor 14 Tahun 1985 Tentang Mahkamah Agung, yaitu bahwa "Mahkamah Agung mempunyai wewenang menguji peraturan perundang-undangan di bawah undang-undang terhadap undangundang dan Mahkamah Agung menyatakan tidak sah peraturan perundang-undangan di bawah undang-undang atas alasan bertentangan dengan peraturan perundangundangan yang lebih tinggi atau pembentukannya tidak memenuhi ketentuan yang berlaku" (Mirawaty, 2009). Sebaiknya organisasi Advokat melakukan permohonan upaya pengujian (judicial review) atas Peraturan Pemerintah Republik Indonesia Nomor 43 Tahun 2015 Tentang Pihak Pelapor Dalam Pencegahan Dan Pemberantasan Tindak Pidana Pencucian Uang Juncto Peraturan Pemerintah Republik Indonesia Nomor 61 Tahun 2021 Tentang Perubahan Atas Peraturan Pemerintah Republik Indonesia Nomor 43 Tahun 2015 Tentang Pihak Pelapor Dalam Pencegahan Dan Pemberantasan Tindak Pidana Pencucian Uang, terhadap UndangUndang Nomor 18 Tahun 2003 Tentang Advokat kepada Mahkamah Agung Republik Indonesia. Hal ini dilakukan agar tercipta kepastian hukum terhadap Advokat dalam menjalankan kewajiban profesinya, serta juga dapat menjadi acuan bagi Advokat dalam mengambil sikap dan tindakan ke depannya, dimana disatu sisi diharuskan untuk menjaga kerahasiaan informasi dari klien, dan disisi yang lain juga diwajibkan menjadi pihak pelapor apabila terdapat indikasi transaksi keuangan mencurigakan dalam penanganan perkara klien yang sedang ditanganinya.

\section{Kesimpulan}

Kewenangan yang diberikan kepada Advokat untuk bertindak sebagai pihak pelapor terkait adanya dugaan transaksi keuangan mencurigakan, terbentur dengan kewajiban Advokat untuk merahasiakan informasi yang diperoleh dari kliennya. Namun demikian, walaupun Advokat terikat pada kewajiban menurut undang-undang dan Kode Etik Profesi guna menjaga kerahasiaan informasi dari klien, akan tetapi dalam rangka upaya mencegah praktik transaksi keuangan mencurigakan serta guna memberantas tindak pidana pencucian uang, Advokat dapat mengesampingkan etika dan kewajibannya, sehingga diperbolehkan untuk melaporkan segala transaksi keuangan mencurigakan yang berindikasi pada tindak pidana pencucian uang sekalipun berasal dari kliennya sendiri, karena hal tersebut sudah bukan lagi masalah hubungan privilege kerahasiaan antara Advokat dan klien, akan tetapi jauh lebih besar lagi menyangkut kepentingan negara dan masyarakat luas yang jelas dirugikan oleh karena perbuatan 
pencucian uang. Sudah merupakan kewajiban Advokat menurut undang-undang dan etika profesi untuk menjaga kerahasiaan informasi dari kliennya, namun kewajiban tersebut haruslah selaras dengan ketentuan peraturan perundang-undangan yang berlaku. Tidak boleh seorang Advokat, sebagai bagian dari penegak hukum, dapat dikontrol secara berlebihan oleh klien dengan mengacuhkan ketentuan hukum yang telah ditetapkan. Bahwa terkait dengan kerahasiaan informasi yang dimaksud tersebut, bukanlah berarti menjaga rahasia secara keseluruhan tanpa batas, tetapi apabila sudah menyangkut kepada kepentingan negara dan masyarakat luas terkait transaksi keuangan mencurigakan yang berindikasi pada tindak pidana pencucian uang, maka membuka rahasia informasi menjadi suatu kewajiban profesi dalam rangka proses penegakan hukum. Namun demikian, demi terciptanya kepastian hukum terkait dengan kedudukan Advokat dalam kewajibannya menjaga kerahasiaan informasi dari klien, dihubungkan dengan kewajiban lainnya sebagai pihak pelapor apabila ada dugaan transaksi keuangan mencurigakan yang berindikasi pada tindak pidana pencucian uang, perlu dilakukan upaya pengujian (judicial review) atas Peraturan Pemerintah Republik Indonesia Nomor 43 Tahun 2015 Tentang Pihak Pelapor Dalam Pencegahan Dan Pemberantasan Tindak Pidana Pencucian Uang Juncto Peraturan Pemerintah Republik Indonesia Nomor 61 Tahun 2021 Tentang Perubahan Atas Peraturan Pemerintah Republik Indonesia Nomor 43 Tahun 2015 Tentang Pihak Pelapor Dalam Pencegahan Dan Pemberantasan Tindak Pidana Pencucian Uang, terhadap Undang-Undang Nomor 18 Tahun 2003 Tentang Advokat, kepada Mahkamah Agung Republik Indonesia. 


\section{BIBLIOGRAFI}

Fadjar, A. M. (2003). Reformasi Konstitusi Dalam Masa Transisi Paradigmatik. Institute for Strengthening Transition Society Studies. Google Scholar

Hsb, A. M. (2011). Undang-Undang Nomor 12 Tahun 2011 Tentang Pembentukan Peraturan Perundang-Undangan. Kashva Publishing. Google Scholar

Indonesia, K. K. A. (2002). Kode Etik Advokat Indonesia. Panitia Daerah Ujian Kode Etik Advokat Indonesia, Jakarta. Google Scholar

Indonesia, R. (2010). Undang-Undang Nomor 8 Tahun 2010 Tentang Pencegahan dan Pemberantasan Tindak Pidana Pencucian Uang. Lembaran Negara RI Tahun. Google Scholar

Lotulung, P. E. (1994). Himpunan Makalah Azas-Azas Umum Pemerintahan Yang Baik. Google Scholar

Manullang, E. F. M., \& Berkeadilan, M. H. (2007). Tinjauan Hukum Kodrat dan Antinomi Nilai. Penerbit Buku Kompas, Jakarta. Google Scholar

Marzuki, P. M., \& SH, M. S. (2021). Pengantar ilmu hukum. Prenada Media. Google Scholar

Mirawaty, M. (2009). Eksistensi Undang-Undang Nomor 3 Tahun 2009 tentang Perubahan kedua atas Undang-undang Nomor 14 tahun 1985 tentang Mahkamah Agung dilihat dari Tata cara pembentukan Peraturan Perundang-undangan/oleh Mirawaty. Universitas Tarumanagara. Google Scholar

Nomor, U.-U. R. I. (12 C.E.). tahun 2011 tentang Pembentukan Peraturan Perundangundangan. Jakarta: Penerbit Kerjasama Antara Kementrian Hukum Dan Hak Asasi Manusia Republik Indonesia Direktorat Jenderal Peraturan Perundang-Undangan Dengan Hanns Seidel Fondation. Google Scholar

Parera, T. Y. (2018). Advokat dan penegakan hukum. Google Scholar

Pattawijaya, R. (2021). Analisis Undang-Undang Nomor 18 Tahun 2003 Tentang Advokat Persfektif Hukum Islam (Studi Pasal 26 Tentang Kode Etik Advokat). UIN FAS Bengkulu. Google Scholar

Rahardjo, S., \& Dimyati, K. (2002). Sosiologi hukum: perkembangan, metode, dan pilihan masalah. Muhammadiyah University Press. Google Scholar

Soekanto, S. (2007). Faktor-faktor yang mempengaruhi penegakan hukum. Google Scholar

Wairocana, G. N. (2008). Implementasi Good Governence dalam Legislasi Daerah. Orasi Ilmiah Fakultas Hukum. Google Scholar 
Yudhi Ongkowijaya, Helvis, Markoni

Yuristara, R. A. S. (2018). Pertanggungjawaban Advokat Sebagai Gatekeeper Dalam Kaitannya Dengan Tindak Pidana Pencucian Uang. Media Iuris, 1 (2), 350-372. Google Scholar

\section{Copyright holder:}

Yudhi Ongkowijaya, Helvis, Markoni (2021)

First publication right:

Jurnal Syntax Admiration

This article is licensed under:

(c) () (2) 